\title{
Peranan Majelis Pengawas Wilayah atas Penjatuhan Sanksi Terhadap Notaris yang Tidak Membacakan Akta
}

\author{
Arifani Kurnia \\ arphan_07@yahoo.com
}

\begin{abstract}
The problems in this research include, first, what is the role of the Regional Notary Supervisory Council in imposing sanctions on notaries who do not read deeds? Second, what is the legal consequence for a notary who does not read the deed based on the Decision of Yogyakarta Regional Supervisory Council Number 03/Pt/Mj.PWN DDIY/VI/2016? and third, what is the legal consideration of Yogyakarta Regional Supervisory Council in imposing sanctions on the notary? This study is normative-empirical legal research with a field research type. The results indicate that, first, the role of Notary Supervisory Council is to protect the interests of the community or parties who suffer losses due to legal actions by irresponsible notaries who conduct their duties without referring to the stipulated provisions in both the law and decisions of the notary professional association/organization. Second, the legal consequence for the notary based on the Decision of Yogyakarta Regional Supervisory Council Number 03/Pts/Mj.PWN DIY/VI/2016 is in the form of written notice in which the decision can be used as a reason for a case reporter to sue the concerned notary for a civil compensation. Third, the legal basis for imposing sanctions on the notary, which is the result of investigation stating that the notary has been found guilty, is not a violated formal requirement.
\end{abstract}

Keywords: Notary; deed; notary supervisory council

\begin{abstract}
Abstrak
Permasalahan yang diangkat dalam penelitian ini pertama, bagaimana peranan Majelis Pengawas Notaris Wilayah atas penjatuhan sanksi terhadap Notaris yang tidak membacakan akta? Kedua, apa akibat hukum terhadap Notaris yang tidak membacakan akta berdasarkan Putusan Majelis Pengawas Wilayah Daerah Istimewa Yogyakarta Nomor 03/Pt/Mj.PWN DDIY/VI/2016? Ketiga, apa dasar pertimbangan hukum Majelis Pengawas Wilayah Daerah Istimewa Yogyakarta dalam menjatuhkan sanksi bagi Notaris tersebut? Jenis penelitian yang digunakan dalam penelitian ini adalah, penelitian hukum normatif-empiris, dan menggunakan jenis penelitian lapangan (field research). Hasil dari penelitian ini menyimpulkan, pertama, peranan Majelis Pengawas Notaris untuk menyelamatkan kepentingan masyarakat atau pihak yang mengalami kerugian akibat dari perbuatan hukum yang timbul karena Notaris yang tidak bertanggungjawab dan dalam menjalankan tugas jabatannya tidak memperhatikan ketentuan-ketentuan yang telah ditentukan baik di dalam Undang-undang maupun berdasarkan keputusan perkumpulan/organisasi Profesi Notaris. Kedua, akibat hukum bagi Notaris berdasarkan putusan Majelis Pengawas Wilayah Daerah Istimewa Yogyakarta Nomor 03/Pts/Mj.PWN $\mathrm{DIY} / \mathrm{VI} / 2016$ berupa peringatan tertulis yaitu, putusan tersebut bisa digunakan sebagai alasan pelapor untuk menggugat kepada Notaris yang bersangkutan untuk meminta ganti rugi secara perdata. Ketiga, Dasar hukum penjatuhan sanksi terhadap Notaris tersebut yakni pada pemeriksaan Notaris tersebut telah terbuki bersalah, bukan merupakan persyaratan formal yang dilanggar.
\end{abstract}

Kata-kata Kunci: Notaris; akta; majelis pengawasan notaris 


\section{Pendahuluan}

Hubungan antara masyarakat dan hukum diungkapkan dengan sebuah adagium yang sangat terkenal dalam ilmu hukum, yaitu "ubi societes ibi ius" yang artinya dimana ada masyarakat disana ada hukum, ${ }^{1}$ dalam hal ini, Notaris adalah pejabat umum yang berwenang untuk membuat akta autentik berdasarkan Undang-undang Jabatan Notaris atau undang-undang lainnya. ${ }^{2}$ Tujuan dibuatnya akta autentik adalah sebagai alat pembuktian ${ }^{3}$ di muka maupun di luar pengadilan.

Akta di bawah tangan mempunyai kekuatan pembuktian sepanjang para pihak mengakuinya atau tidak ada penyangkalan dari salah satu pihak, ${ }^{4}$ jika para pihak mengakuinya, maka akta di bawah tangan tersebut mempunyai kekuatan hukum pembuktian yang sempurna sebagaimana akta autentik, 5 jika ada salah satu pihak yang tidak mengakuinya, beban pembuktian diserahkan kepada pihak yang menyangkal akta tersebut, dan nilai penyangkalan atas bukti tersebut diserahkan kepada hakim.

Alat bukti akta di bawah tangan maupun akta autentik keduanya harus memenuhi rumusan mengenai syarat sahnya suatu perjanjian berdasarkan Pasal 1320 KUHPerdata, dan secara materiil mengikat para pihak yang membuatnya sebagai suatu perjanjian yang harus ditepati oleh para pihak (pacta sun servanda). ${ }^{6}$

Disebut akta Notaris, karena akta tersebut sebagai akta autentik yang dibuat di hadapan atau oleh Notaris yang memenuhi syarat yang telah ditentukan oleh

${ }^{1}$ Satjipto Rahardjo, Masalab Penegakan Hukum, Suatu Tinjauan Sosiologis, Sinar Baru, Bandung, 1983, hlm.127.

${ }^{2}$ Lihat Pasal 1 angka 1 Undang-undang Nomor 2 Tahun 2014 tentang Perubahan Atas Undang-Undang Nomor 30 Tahun 2004 tentang Jabatan Notaris.

3 Alat bukti yang sah atau yang diakui oleh hukum menurut hukum acara perdata, terdiri dari (Pasal 138, 165, 167 HIR, 164, 285-305 Rbg, Stb. 1867 Nomor 29.):

a. Bukti tulisan.

b. Bukti dengan saksi-saksi.

c. Persangkaan-persangkaan.

d. Pengakuan.

e. Sumpah.

${ }_{4}$ Sebagai contoh putusan Mahkamah Agung RI Nomor 775 K/Sip/1971, tanggal 06 Oktober 1971, menegaskan bawa surat (surat jual beli) yang diajukan dalam persidangan, kemudian disangkal oleh pihak lawan, dan tidak dikuatkan dengan alat bukti lainnya, maka surat (jual beli tanah) tersebut dinilai sebagai alat bukti yang lemah dan belum sempurna. M. Ali Boediarto, Kompilasi Kaidah Hukum Putusan Mabkamah Agung, Hukum Acara Perdata Setengah Abad, Swa Justicia, Jakarta, 2005, hlm. 145.

${ }^{5}$ Lihat Pasal 1875 KUHPerdata.

${ }^{6}$ Lihat Pasal 1338 KUHPerdata. 
Undang-undang Jabatan Notaris, yaitu Pasal 1 angka 1 Undang-Undang Nomor 2 Tahun 2014 tentang Perubahan Atas Undang-Undang Nomor 30 Tahun 2004 tentang Jabatan Notaris (selanjutnya disebut UUJN-P). Akta Notaris sudah pasti akta autentik, tetapi akta autentik bisa juga akta Notaris, akta Pejabat Pembuat Akta Tanah, risalah lelang Pejabat Lelang dan akta Catatan Sipil. ${ }^{7}$

Notaris merupakan profesi hukum, dengan demikian profesi Notaris adalah suatu profesi mulia (officium nobile), 8 dikarenakan profesi Notaris sangat erat hubungannya dengan kemanusiaan. Akta yang dibuat oleh Notaris dapat menjadi alas hukum atas status harta benda, hak dan kewajiban seseorang. ${ }^{9}$

Notaris adalah profesi yang sangat penting dan dibutuhkan dalam masyarakat dimana peranan dalam lalu lintas hukum kehidupan bermasyarakat melalui akta autentik yang dibuat oleh atau dihadapannya, mengingat akta autentik sebagai alat bukti terkuat dan memiliki nilai yuridis yang esensial dalam setiap hubungan hukum bila terjadi sengketa dalam kehidupan masyarakat. Tugas Notaris adalah mengkonstantir hubungan hukum antara para pihak dalam bentuk tertulis dan format tertentu, sehingga merupakan suatu akta autentik. Notaris adalah pembuat dokumen yang kuat dalam suatu proses hukum. ${ }^{10}$

Notaris pada hakikatnya adalah sebagai pejabat umum yang ditugaskan oleh kekuasaan umum untuk melayani kebutuhan masyarakat akan alat bukti autentik yang memberikan kepastian hukum perdata, jadi sepanjang alat bukti diperlukan oleh sistem hukum negara maka jabatan Notaris akan tetap diperlukan eksistensinya di tengah masyarakat. ${ }^{11}$

Sebelum berlakunya Undang-Undang Jabatan Notaris, pemeriksaan, pengawasan dan penjatuhan sanksi terhadap Notaris dilakukan oleh badan peradilan yang ada pada waktu itu, sebagaimana pernah diatur dalam Pasal 140 Reglement op de Rechtelijke Organisatie en Het Der Justitie, ${ }^{12}$ kemudian pengawasan

\footnotetext{
${ }^{7}$ Habib Adjie, Kebatalan dan Pembatalan Akta Notaris, Refika Aditama, Badung, 2013, hlm. 78.

${ }^{8}$ Istilah officium nobile, juga disebut sebagai suatu pekerjaan yang terhormat.

${ }_{9}^{9}$ Abdul Ghofur Anshori, Lembaga Kenotariatan Indonesia, Perspektif Hukum dan Etika, UII Press, Yogyakarta, 2009, hlm. 25.

10 Tan Thong Kie, Studi Notariat, Beberapa Mata Pelajaran dan Serba-Serbi Praktek Notaris, Buku I, cet. ke-2, Ichtiar Baru Van Hoeve, Jakarta, 2000, hlm.159.

11 G.H.S. Lumban Tobing, Peraturan Jabatan Notaris (Notaris Reglement), Erlangga, Jakarta, 1999, hlm. 41.

12 Stbl. 1847 No. 23, Pasal 96 Reglement Buitengewestern, Pasal 3 Ordonantie Buitengrechtelijke VerrichtingenLembaran Negara 1946 Nomor 135, dan Pasal 50 Peraturan Jabatan Notaris.
} 
terhadap Notaris dilakukan Peradilan Umum dan Mahkamah Agung sebagaimana tersebut dalam Pasal 32 dan 54 Undang-Undang Nomor 13 Tahun 1965 tentang Pengadilan dalam Lingkungan Peradilan Umum dan Mahkamah Agung.

Kemudian dibuatkan pula Surat Edaran Mahkamah Agung Republik Indonesia Nomor 2 Tahun 1984 tentang Tata Cara Pengawasan Terhadap Notaris, keputusan Bersama Ketua Mahkamah Agung dan Menteri Kehakiman Nomor KMA/006/SKB/VII/1987 tentang Tata Cara Pengawasan, Penindakan dan Pembelaan Diri Notaris, dan terakhir dalam Pasal 54 Undang-undang Nomor 8 Tahun 2004 tentang Perubahan Atas Undang-undang Nomor 2 Tahun 1986 tentang Peradilan Umum.

Dalam kaitan tersebut di atas, meski Notaris diangkat oleh pemerintah, ${ }^{13}$ mengenai pengawasannya dilakukan oleh badan peradilan, hal ini dapat dipahami karena pada waktu itu kekuasaan kehakiman ada pada Departemen Kehakiman. Pada 1999 sampai dengan 2001 dilakukan perubahan terhadap Undang-Undang Dasar 1945, dan dengan amandemen tersebut telah pula merubah kekuasaan keha Majelis Pengawas Notaris adalah suatu badan yang mempunyai kewenangan dan kewajiban untuk melaksanakan pembinaan dan pengawasan terhadap Notaris. ${ }^{14}$ Ketentuan dalam Pasal 68 UUJN menjelaskan bahwa Majelis Pengawas Notaris terdiri atas Majelis Pengawas Daerah, Majelis Pengawas Wilayah, dan Majelis Pengawas Pusat. ${ }^{15}$ Wewenang Majelis Pengawas Notaris, salah satunya yaitu menyelenggarakan sidang untuk memeriksa adanya dugaan pelanggaran kode etik Notaris atau pelanggaran pelaksanaan jabatan Notaris.

Dalam melaksanakan tugasnya untuk melayani kepenting masyarakat, Notaris seharusnya menjaga harkat martabatnya. Tan Thong Kie ${ }^{16}$ menyatakan bahwa terdapat kebiasaan di kalangan Notaris yang tidak lagi membaca aktanya sehingga akta itu menjadi akta di bawah tangan. Di dalam akta Notaris menuliskan

\footnotetext{
${ }^{13}$ Dahulu oleh Menteri Kehakiman, sekarang oleh Menteri Hukum dan Hak Asasi Manusia.

${ }^{14}$ Lihat Pasal 1 angka 6 UUJN-P

${ }^{15}$ Lihat Pasal 68 UUJN.

${ }^{16}$ Tan Thong Kie, Studi Notariat Serba-serbi Praktek Notaris, Ikhtiar Baru, Jakarta, 2007, hlm. 634.
} 
bahwa akta itu "telah dibacakan oleh saya, Notaris", padahal ia tidak pernah membacakannya.

Perbuatan tersebut merupakan pemalsuan akta, terlebih banyak Notaris membiarkan para penghadap menandatangani akta di hadapan asistennya, sehingga keterangan Notaris tersebut "telah berhadapan dengan pengahadap" perlu diragukan pula. Bahwa dengan tidak membaca akta dan tidak melihat siapa yang menandatangani akta, Notaris yang berbuat demikian menurunkan martabat jabatan dan pekerjaan yang mulia. ${ }^{17}$

Pelanggaran jabatan maupun kode etik Notaris, dapat menimbulkan rasa ketidakpercayaan masyarakat kepada Notaris sebagai pejabat umum yang membuat akta autentik. Dalam ketentuan Pasal 70 huruf g Undang-Undang Jabatan Nomor 30 Tahun 2004 tentang Jabatan Notaris menyatakan bahwa UUJN hanya memberikan kewenangan kepada Majelis Pengawas Daerah (MPD) untuk menerima laporan dari masyarakat mengenai adanya dugaan pelanggaran kode etik, maka dari itu MPD tidak dapat menindak tanpa adanya laporan dari masarakat atau pihak yang merasa dirugikan atas perbuatan hukum yang dilakukan oleh seorang Notaris.

Putusan Majelis Pengawas Notaris Wilayah Daerah Istimewa Yogyakarta Nomor 03/Pts/Mj.PWN DIY/VI/2016 merupakan salah satu contoh putusan atas terjadinya pelanggaran jabatan dan kode etik yang dilakukan oleh seorang Notaris. Permasalahan ini muncul pada saat pelapor melaporkan seorang Notaris di Kabupaten Sleman dengan dasar bahwa Notaris tersebut melanggar ketentuan kode etik Notaris, Majelis Pengawas Wilayah Daerah Istimewa Yogyakarta dalam proses sidangnya, menemukan fakta hukum bahwa Notaris yang bersangkutan melanggar beberapa ketentuan kode etik, yaitu:

Pertama, penandatanganan akta kuasa menjual, tidak ditandatangani secara langsung/bersamaan, penerima kuasa lebih dahulu menandatangani akta kuasa tersebut. Kedua, Notaris tidak membacakan akta di hadapan penghadap. Ketiga, Notaris tidak mengecek keaslian identitas penghadap, Notaris hanya melihat fotocopy identitas penghadap. Dari kejadian tersebut, penghadap merasa dirugikan

${ }^{17}$ Endang Purwaningsih, "Bentuk Pelanggaran hukum Notaris di wilayah Provinsi Banten dan Penegakan Hukumnya”, Jurnal Bidang Hukum Bisnis, Fakultas Hukum YARSI, Jakarta, 2014. 
atas perbuatan Notaris yang bersangkutan. Apabila dilihat ketentuan Pasal 16 ayat (1) huruf m UUJN-P, bahwa Notaris wajib membacakan akta di hadapan penghadap, setidaknya 2 orang saksi serta bersamaan itu juga dilakukan penadatanganan.

Berdasarkan latar belakang tersebut di atas penulis tertarik untuk membahasnya dalam bentuk penelitian yang berjudul "Peranan Majelis Pengawas Wilayah atas Penjatuhan Sanksi terhadap Notaris yang tidak Membacakan Akta" (Analisis terhadap Putusan Majelis Pengawas Wilayah Daerah Istimewa Yogyakarta Nomor 03/Pts/Mj.Pwn Diy/Vi/2016).

\section{Rumusan Masalah}

Pertama, bagaimana peranan Majelis Pengawas Notaris Wilayah atas penjatuhan sanksi terhadap Notaris yang tidak membacakan aktanya? Kedua, apa akibat hukum terhadap Notaris yang tidak membacakan akta berdasarkan Putusan Majelis Pengawas Wilayah Daerah Istimewa Yogyakarta Nomor 03/Pts/Mj.PWN DIY/VI/2016? Ketiga, apa dasar pertimbangan hukum Majelis Pengawas Wilayah Daerah Istimewa Yogyakarta dalam menjatuhkan sanksi bagi Notaris tersebut?

\section{Tujuan Penelitian}

Tujuan penelitian ini adalah: pertama, untuk mengkaji peranan Majelis Pengawas Notaris Wilayah atas penjatuhan sanksi terhadap Notaris yang tidak membacakan aktanya. Kedua, untuk mengkaji akibat hukum terhadap Notaris yang tidak membacakan akta berdasarkan Putusan Majelis Pengawas Wilayah Daerah Istimewa Yogyakarta Nomor 03/Pts/Mj.PWN DIY/VI/2016. Ketiga, untuk mengkaji dasar pertimbangan hukum Majelis Pengawas Wilayah Daerah Istimewa Yogyakarta dalam menjatuhkan sanksi bagi Notaris tersebut.

\section{Metode Penelitian}

Objek penelitian ini adalah Peranan Majelis Pengawas atas Penjatuhan Sanksi terhadap Notaris yang tidak Membacakan Akta (analisis terhadap Putusan Majelis 
Pengawas Wilayah Daerah Istimewa Yogyakarta Nomor 03/Pts/Mj.PWN DIY/VI/2016).

Subjek Penelitian ini adalah pihak yang terkait dan berhubungan dengan masalah penelitian ini, yaitu Majelis Pemeriksa yang dibentuk oleh Majelis Pengawas Notaris Wilayah Daerah Istimewa Yogyakarta untuk memeriksa Notaris yang bersangkutan, subjek penelitian dalam penelitian ini adalah H. Nukman Muhammad, S.H., M.M., M.Kn, sebagai responden serta anggota Majelis Pemeriksa pada Majelis Pengawas Notaris Wilayah Daerah Istimewa Yogyakarta.

Jenis penelitian yang digunakan yaitu penelitian hukum normatif-empiris, karena dalam melaksanakan penelitian, peneliti mengadakan penelitian langsung di lapangan yaitu menggunakan data primer dan ditambahkan dengan bahanbahan kepustakaan sebagai data sekunder guna melengkapi penelitian.

Sifat penelitian yang digunakan dalam penelitian ini adalah menggunakan jenis penelitian lapangan (field research). Penelitian lapangan dilakukan dengan melakukan wawancara langsung kepada subjek yang terkait, yaitu Majelis Pemeriksa yang telah dibentuk oleh Majelis Pengawas Notaris Wilayah Daerah Istimewa Yogyakarta untuk menyelenggarakan sidang atas dugaan pelanggaran kode etik Notaris yang bersangkutan.

Pendekatan penelitian yang digunakan dalam penulisan hukum menurut Peter Mahmud Marzuki adalah sebagai berikut: ${ }^{18}$
a. Pendekatan kasus (case approach)
b. Pendekatan perundang-undangan (statute approach)
c. Pendekatan historis (historical approach)
d. Pendekatan perbandingan (comparative approach)
e. Pendekatan konseptual (conceptual approach)

Adapun pendekatan yang digunakan penulis dari beberapa pendekatan di atas adalah pendekatan perundang-undangan (statute approach) dan pendekatan kasus (case approach). Pendekatan perundangan-undangan adalah pendekatan yang dilakukan dengan menelaah semua Undang-undang dan regulasi yang berkaitan dengan isu hukum yang ditangani. Pendekatan kasus adalah pendekatan yang dilakukan dengan cara melakukan telaah terhadap kasus-kasus yang

\footnotetext{
18 Peter Mahmud Marzuki, Penelitian Hukum, Kencana Prenada Media Group, Jakarta, 2011, hlm. 93
} 
berkaitan dengan isu yang dihadapi yang telah menjadi putusan pengadilan yang telah mempunyai kekuatan hukum yang tetap. ${ }^{19}$

Teknik pengumpulan data dimaksudkan untuk memperoleh data hukum dalam penelitian. Teknik pengumpulan data yang mendukung dan berkaitan dengan pemaparan penelitian ini adalah studi dokumen (studi kepustakaan). Studi dokumen adalah suatu alat pengumpulan data yang dilakukan melalui bahan hukum tertulis dengan mempergunakan content analisys. ${ }^{20}$

Teknik ini berguna untuk mendapatkan landasan teori dengan mengkaji dan mempelajari buku-buku, peraturan perundang-undangan, dokumen, laporan, arsip dan hasil penelitian lainnya baik cetak maupun elektronik yang berhubungan dengan Peranan Majelis Pengawas atas Penjatuhan Sanksi terhadap Notaris yang tidak Membacakan Akta.

Teknik pengumpulan data dilakukan dengan cara: Pertama, data primer adalah data yang diperoleh secara langsung dari objek yang diteliti melalui wawancara, yaitu mengadakan wawancara secara langsung dengan sejumlah responden mengenai sekitar masalah yang diteliti. Pertanyaan-pertanyaan disesuaikan dengan situasi dan kondisi saat berlangsungnya wawancara. Kedua, data sekunder adalah suatu data yang diperoleh secara tidak langsung dari lapangan. Dalam data sekunder ini, dilakukan dengan mengumpulkan buku-buku literatur, media cetak, hasil penelitian, serta tulisan karya ilmiah yang ada hubungannya dengan penelitian ini, antara lain:

1) Undang-Undang Nomor 2 Tahun 2014 Tentang Perubahan Atas UndangUndang Nomor 30 Tahun 2004 tentang Jabatan Notaris.

2) Kitab Undang-Undang Hukum Perdata.

3) Peraturan Menteri Hukum dan Hak Asasi Manusia Nomor 25 Tahun 2014 tentang Syarat dan Tata Cara Pengangkatan, Perpindahan, Pemberhentian, dan Perpanjangan Masa Jabatan Notaris.

${ }^{19}$ Ibid., hlm. 24

${ }^{20}$ Ibid., hlm. 21. 
4) Peraturan Menteri Hukum dan Hak Asasi Manusia Nomor 61 Tahun 2016 tentang Tata Cara Penjatuhan Sanksi Administratif Terhadap Notaris.

5) Peraturan Menteri Hukum dan Hak Asasi Manusia Nomor M.02.PR.08.10 Tahun 2004 tentang Tata Cara Pengangkatan Anggota, Pemberhentian Anggota, Susunan Organisasi, Tata Kerja, dan Tata Cara Pemeriksaan Majelis Pengawas Notaris.

6) Kode Etik Notaris.

7) Putusan Majelis Pengawas Wilayah Daerah Istimewa Yogyakarta Nomor 03/Pts/Mj.PWN DIY/VI/2016.

\section{Hasil Penelitian dan Pembahasan}

Peranan Majelis Pengawas Notaris Wilayah Atas Penjatuhan Sanksi Terhadap Notaris yang Tidak Membacakan Akta

Berdasarkan Pasal 16 Keputusan Menteri Kehakiman dan Hak Asasi Manusia RI Nomor M-01.HT.03.01 Tahun 2003 tentang Kenotarisan, menyatakan bahwa Menteri berwenang melakukan pembinaan dan pengawasan terhadap Notaris. Pembinaan dimaksud meliputi penentuan formasi, pengangkatan, peringatan, penertiban dan pemberhentian. ${ }^{21}$ Dalam pelaksanaannya, Menteri kemudian membentuk badan yang dinamakan Majelis Pengawas Notaris.

Kewenangan pertama kali untuk melakukan pemeriksaan terhadap Notaris yaitu oleh Majelis Pengawas Daerah, Majelis Pengawas Wilayah tidak bisa serta merta ambil alih kewenangan dari Majelis Pengawas Daerah (berjenjang dari MPD, MPW, MPP). Berdasarkan keterangan yang diperoleh dari Bapak Nukman Muhammad $^{22}$ sebagai Anggota Majelis Pemeriksa Majelis pengawas Wilayah DIY, bahwa dalam kasus ini, Notaris X sebagai Terlapor sudah diperiksa oleh Majelis Pengawas Daerah Kabupaten Sleman, atas laporan dari masyarakat yang merasa dirugikan, karena Majelis Pengawas Daerah tidak memiliki kewenangan memutus, MPD hanya memiliki kewenangan memeriksa tingkat pertama, kemudian maksimal hanya memberikan rekomendasai kepada Majelis Pengawas Wilayah. Kewenangan MPW, memberikan teguran atau tertulis, dan usulan kepada MPP

${ }^{21}$ Pasal 16 Keputusan Menteri Kehakiman dan Hak Asasi Manusia RI Nomor M-01.HT.03.01 Tahun 2003 tentang Kenotarisan.

${ }^{22}$ Nukman Muhammmad, Wawancara dilakukuan pada hari Rabu 23 Agustus 2017, pukul 11.30 WIB 
supaya Notaris dijatuni sanksi untuk diberhentikan sementara atau diberhentikan dengan tidak hormat.

Peranan Majelis Pengawas Wilayah terhadap penjatuhan sanksi terhadap Notaris yang melakukan pelanggaran pelaksanaan tugas jabatan, sebagaimana dalam kasus ini Notaris tidak membacakan akta, sangat penting. Hal ini dikarenakan sebagaimana fungsi dari Majelis Pengawas Notaris sendiri adalah suatu badan yang mempunyai kewenangan dan kewajiban untuk melaksanakan pembinaan dan pengawasan terhadap Notaris.

Peranan Majelis Pengawas Notaris untuk menyelamatkan kepentingan masyarakat atau pihak yang mengalami kerugian akibat dari perbuatan hukum yang timbul karena Notaris yang tidak bertanggung jawab dan menjalankan tugas jabatannya tidak memperhatikan ketentuan-ketentuan yang telah ditentukan oleh undang-undang maupun keputusan perkumpulan/organisasi profesi Notaris.

Selain untuk menyelamatkan kepentingan masyarakat, Kepala Kantor Wilayah Kemenkumham NTB menyakan bahwa pengawasan terhadap Notaris pada dasarnya merupakan wujud dari perlindungan hukum terhadap Notaris itu sendiri. Oleh karena dengan adanya suatu pengawasan, tiap notaris dalam berperilaku dan bertindak selalu dalam koridor hukum. ${ }^{23}$

Pengawasan Notaris dibedakan antara perilaku dan tindakan yang dilakukan oleh Notaris dalam menjalankan jabatanya oleh Majelis Pengawas Notaris, sedangkan perilaku dan tindakan yang dilakukan oleh Notaris di luar menjalankan jabatanya diawasi oleh badan yang dibentuk oleh organisasi Notaris, yaitu Dewan Kehormatan Notaris.

Badan lain yang bertugas untuk memberikan pembinaan terhadap Notaris, berdasarkan Pasal 66A UUJN-P adalah Majelis Kehormatan Notaris. Majelis Kehormatan Notaris berdasarkan Peraturan Menteri Hukum dan Hak Asasi Manusia Nomor 7 Tahun 2016 tentang Majelis Kehormatan Notaris yang terdapat

${ }^{23}$ Sambutan Kepala Kantor Wilayah Kemenkumham NTB dalam menyelenggarakan kegiatan pembinaan dan pengawasan Majelis Pengawas Pusat Notaris (MPPN) di Aula Kantor Wilayah Kemenkumham NTB 09 Juni 2017, http://ntb.kemenkumham.go.id/pusat-informasi/artikel/2348-kegiatan-pembinaan-dan-pengawasanmajelis-pengawas-notaris. 
pada Pasal 1 angka 1 mendefinisikan "Majelis Kehormatan Notaris adalah suatu badan yang mempunyai kewenangan untuk melaksanakan pembinaan Notaris dan kewajiban memberikan persetujuan atau penolakan untuk kepentingan penyidikan dan proses peradilan atas pengambilan fotokopi minuta akta dan pemanggilan Notaris untuk hadir dalam pemeriksaan yang berkaitan dengan akta atau protokol Notaris yang berada dalam penyimpanan Notaris." 24

Dari penjelasan di atas dapat dipahami bahwa seorang Notaris dalam menjalan jabatannya terdapat 3 badan yang memberikan pengawasan dan pembinaan. Majelis Pengawas Notaris yang dibentuk oleh undang-undang yang berwenang untuk meberikan pengawasaan terhadap pelaksanaan jabatan Notaris, Dewan Kehormatan Notaris adalah badan yang dibentuk perkumpulan Ikatan Notaris Indonesia yang berwenang memberikan pengawasan terkait kode etik Notaris, dan Majelis Kehormatan Notaris yang berwennag memberikan pembinaan terhadap Notaris.

Keberadaan Majelis Pengawas Notaris dalam Undang-Undang Nomor 2 Tahun 2014 tentang Perubahan Atas Undang-Undang Nomor 30 Tahun 2004 tentang Jabatan Notaris, diperkuat lagi dengan Peraturan Menteri Hukum dan Hak Asasi Manusia Nomor 61 Tahun 2016 tentang Tata Cara Penjatuhan Sanksi Administratif Terhadap Notaris.

Pasal 5 ayat (1) Permenkumham tersebut menjelaskan bahwa, Majelis Pengawas Wilayah dapat menjatuhkan sanksi peringatan tertulis kepada Notaris dalam hal Notaris: 25

a. tidak menjalankan jabatan secara nyata. Yang meliputi: menyampaikan berita acara sumpah/janji jabatan Notaris kepada Menteri, Organisasi Notaris, dan Majelis Pengawas Daerah serta tidak menyampaikan alamat kantor, contoh tanda tangan, dan paraf, serta teraan cap atau stempel jabatan Notaris berwarna merah kepada Menteri dan pejabat lain yang bertanggung jawab di bidang pertanahan, Organisasai Notaris, Ketua Pengadilan Negeri, Majelis Pengawas Daerah, serta Bupati/Walikota di tempat Notaris diangkat sesuai dengan ketentuan Pasal 7 ayat (1) Undang-Undang Jabatan Notaris.

${ }^{24}$ Pasal 1 angka 1 Peraturan Menteri Hukum dan Hak Asasi Manusia Nomor 7 Tahun 2016 tentang Majelis Kehormatan Notaris.

${ }^{25}$ Lihat ketentuan dalam Pasal 5 ayat (1) Peraturan Menteri Hukum dan Hak Asasi Manusia Nomor 61 Tahun 2016 tentang Tata Cara Penjatuhan Sanksi Administratif Terhadap Notaris. 
b. tidak melakukan kewajibannya dalam menjalankan jabatannya sebagai Notaris sesuai dengan ketentuan Pasal 16 Undang-Undang Jabatan Notaris mengenai kewajiban Notaris.

c. melakukan larangan dalam menjalankan jabatannya sebagai Notaris sesuai dengan ketentuan Pasal 17 ayat (1) Undang-Undang Jabatan Notaris.

d. mempunyai alamat kantor lebih dari satu, tempat kedudukan Pejabat Pembuat Akta Tanah diluar tempat kedudukan Notaris dan menjalankan jabatannya secara berturut-turut diluar tempat kedudukannya sesuai dengan Pasal 19 ayat (1) Undang-Undang Jabatan Notaris.

e. menjalankan cuti namun tidak menyerahkan Protokol Notaris kepada Notaris Pengganti, Notaris Pengganti tidak menyerahkan kembali Protokol Notaris kepada Notaris setelah cuti berakhir dan tidak membuat berita acara serah terima Protokol Notaris sesuai dengan Pasal 32 ayat (1), ayat (2) dan ayat (3) Undang-Undang Jabatan Notaris.

f. tidak memberikan jasa hukum dibidang kenotariatan secara cuma-cuma kepada orang yang tidak mampu sesuai dengan ketentuan Pasal 37 ayat (1) Undang-Undang Jabatan Notaris.

g. memberikan, memperlihatkan atau memberitahukan isi Akta, Grosse Akta, Salinan Akta dan Kutipan Akta kepada orang yang tidak berkepentingan langsung pada pembuatan Akta sesuai dengan ketentuan Pasal 54 ayat (1) Undang-Undang Jabatan Notaris.

h. tidak melakukan pembuatan, penyimpanan, dan penyerahan Protokol Notaris sesuai dengan ketentuan Pasal 58 dan Pasal 59 Undang-Undang Jabatan Notaris.

\section{Akibat Hukum Terhadap Notaris yang Tidak Membacakan Akta Berdasarkan Putusan Majelis Pengawas Wilayah Daerah Istimewa Yogyakarta Nomor 03/Pts/Mj.PWN DIY/VI/2016}

Akibat hukum adalah suatu akibat yang ditimbulkan oleh hukum, terhadap suatu perbuatan yang dilakukan oleh subjek hukum. ${ }^{26}$ Akibat hukum bagi Notaris yang tidak melakukan kewajiban pembacaan akta yaitu Notaris akan dikenakan sanksi perdata yaitu adanya pihak yang merasa dirugikan karena akta terdegradasi, para pihak menuntut penggantian biaya, ganti rugi, dan bunga kepada Notaris.

Sanksi administratif 27 yaitu sanksi yang dikenakan terhadap jabatan Notaris, berupa peringatan tertulis, pemberhentian sementara, pemberhentian dengan

26 Achmad Ali, Menguak Teori Hukum (Legal Theory) dan Teori Peradilan (Judicialprudence) Termasuk Interpretasi Undang-undang (Legisprudence), Kencana, Jakarta, 2009, hlm. 192.

${ }^{27}$ Habib Adjie, Sanksi Perdata, Op. Cit. 
hormat, atau pemberhentian dengan tidak hormat. Sanksi Pidana yaitu Notaris dapat dikenakan pasal-pasal mengenai tindak pidana pemalsuan sehubungan dengan kewenangannya membuat akta, apabila akta yang dibuatnya tidak sesuai dengan keterangan keadaan penghadap yang sebenarnya.

Akibat hukum terhadap Notaris sebagaimana tersebut di atas, Majelis Pengawas Wilayah Daerah Istimewa Yogyakarta memberikan sanksi berupa peringatan tertulis. Sanksi berupa peringatan tertulis diberikan kepada Notaris $X$, berdasarkan wawancara dengan Bapak Nukman Muhammad ${ }^{28}$ sebagai anggota Majelis Pemeriksa, dikarenakan Notaris tersebut memang terbukti bersalah, akan tetapi ia hanya melanggar prosedur, sedang syarat formal dalam proses pembuatan akta tidak ada yang dilanggar. Apabila dalam kasus di atas terdapat syarat formal yang dilanggar, maka akta tersebut menjadi akta di bawah tangan. Dengan kata lain, akta tersebut tetap memiliki eksistensi. Apabila suatu akta Notaris tidak berdasarkan ketentuan sebagaimana yang ditentukan dalam Pasal 38 UUJN, maka akta tersebut menjadi akta di bawah tangan.

Sedangkan mengenai syarat materiil, telah diatur pada ketentuan Pasal 1320 Kitab Undang-undang Hukum Perdata, meliputi:

1) Adanya kesepakatan kedua belah pihak.

2) Kecakapan untuk melakukan perbuatan hukum.

3) Adanya Obyek.

4) Adanya kausa yang halal.

Apabila akta Notaris tidak memenuhi syarat obyektif sebagaimana ketentuan Pasal 1320 Kitab Undang-Undang Hukum Perdata, maka akta tersebut batal demi hukum.

Akibat hukum bagi pelapor setelah penjatuhan sanksi Notaris X diberikan sanksi berupa peringatan tertulis yaitu putusan Majelis Pengawas Wilayah Daerah Istimewa Yogyakarta Nomor 03/Pts/Mj.PWN DIY/VI/2016, bisa digunakan sebagai dasar pelapor untuk menggugat kepada Notaris $X$ untuk ganti rugi secara perdata.

28 Wawancara Nukman Muhammmad, sebagai Anggota Majelis Pemeriksa yang dibentuk oleh Majelis Pengawas Wilayah DIY, wawancara dilakukan pada hari Senin 21 Agustus 2017, pukul 11.00 WIB. 


\section{Dasar Pertimbangan Hukum Majelis Pengawas Wilayah Daerah Istimewa Yogyakarta dalam Menjatuhkan Sanksi bagi Notaris tersebut}

Majelis Pemeriksa dalam proses persidangan, ia sebagai Hakim. Dalam memberikan telaah kepada Pertimbangan Hakim dalam berbagai putusannya akan dilihatnya pada dua kategori. Kategori pertama akan dilihat dari segi pertimbangan yang bersifat yuridis dan kedua adalah pertimbangan yang bersifat non yuridis, yakni: 29

1. Pertimbangan yuridis adalah pertimbangan Hakim yang didasarkan kepada fakta-fakta yang terungkap di dalam persidangan yang muncul dari alat-alat bukti atau hal-hal yang telah ditetapkan oleh undang-undang sebelumnya.

2. Pertimbangan non yuridis adalah pertimbangan Hakim yang didasarkan kepada fakta-fakta yang terungkap saat pemeriksaan berlangsung yang sebelumnya tidak diatur di dalam Undang-undang.

Pada proses sidang Majelis Pemeriksa Majelis Pengawas Wilayah Daerah Istimewa Yogyakarta, terbukti di dalam persidangan bahwa Pelapor mengetahui secara jelas proses penandatanganan kuasa menjual, hanya saja proses penandatangan itu tidak secara bersamaan. Menurut Bapak Nukman Muhammad, bahwa frasa dalam Pasal 44 UUJN, "segera setelah Akta dibacakan, Akta tersebut ditandatangani oleh setiap penghadap, saksi, dan Notaris, ...."

Frasa tersebut di atas tidak dijelaskan secara lebih lanjut atau dijelaskan mengenai waktunya, sehingga mengandung multi tafsir. Dalam hal ini bisa saja akta bersamaan itu juga dalam jam yang sama ditandatangani oleh semua pihak yang terkait, bisa jadi pula penandatanganan akta tersebut dilakukan dalam hari itu pula. Karena dalam kasus di atas, Notaris/terlapor, telah menunggu kehadiran Pelapor di kantornya, akan tetapi Pelapor belum datang, kemudian karena anak Terlapor sakit, Notaris/Terlapor harus menjemput anaknya.

Setelah itu, Pelapor datang untuk melakukan penandatanganan akta, kemudian pegawai Notaris telah mengubungi Terlapor via telepon, dan dengan persetujuan dari Pelapor bahwa Pelapor bersedia apabila pegawai Notaris/Terlapor yang membacakan akta. Pegawai Notaris/Terlapor juga sudah

\footnotetext{
${ }^{29}$ Rusli Muhammad. Potret Lembaga Pengadilan Indonesia, Raja Grafindo Persada, Jakarta, 2006, hlm. 175
} 
menanyakan mengenai kejelasan isi akta yang dibacakannya. Artinya, ketentuan dalam Pasal 16 ayat (7) UUJN mengenai pembacaan akta sudah dilalui.

Apabila Pelapor berpendapat bahwa Pegawai Notaris/Terlapor membacakannya secara cepat sehingga Pelapor merasa tidak memahaminya, menurut Bapak Nukman Muhammad, pendapat itu hanya mengada-ada, karena seorang Klien berhak menanyakan apabila terdapat ketidakjelasan mengenai isi akta. Laporan ini muncul setelah objek terjual, maka Pelapor mencari selah kesalahan Notaris/Terlapor. Menurut Bapak Nukman Muhammad Notaris tersebut memang terbuki bersalah, tetapi tidak berakibat fatal, tapi perlu ditegur/peringatkan, maka keputusannya berupa peringatan tertulis.

Sanksi yang dijatuhkan oleh Majelis Pengawas Wilayah Daerah Istimewa Yogyakarta berupa peringatan tertulis, bersifal final, ${ }^{30}$ serta tidak bisa dilakukan upaya banding ke Majelis Pengawas Pusat. Selain berdasar bukan merupakan pelanggaran yang merakibat fatal, dalam proses pemeriksaan Notaris bersifat kooperatif, mengakui kesalahannya serta berjanji untuk tidak mengulanginya.

\section{Penutup}

Dari analisis di atas, dapat disimpulkan bahwa: pertama, peranan Majelis Pengawas Wilayah terhadap penjatuhan sanksi terhadap Notaris sangat penting. Hal ini dikarenakan sebagaimana fungsi dari Majelis Pengawas Notaris sendiri adalah badan yang mempunyai kewenangan dan kewajiban untuk melaksanakan pembinaan dan pengawasan terhadap Notaris. Peranan Majelis Pengawas Notaris untuk menyelamatkan kepentingan masyarakat atau pihak yang mengalami kerugian akibat dari perbuatan hukum yang timbul karena Notaris yang tidak bertanggungjawab dan dalam menjalankan tugas jabatannya tidak memperhatikan ketentuan-ketentuan yang telah ditentukan baik di dalam undang-undang maupun berdasarkan keputusan perkumpulan/organisasi profesi Notaris. Kedua, akibat hukum bagi Notaris yang tidak membacakan akta berdasarkan putusan Majelis Pengawas Wilayah Daerah Istimewa Yogyakarta Nomor 03/Pts/Mj.PWN

${ }^{30}$ Final artinya suatu definitif sifatnya dan tidak memerlukan suatu keputusan atau tindakan lain-lain baik entah itu dari Pejabat yang berbuat atau instansi lain. Suatu keputusan itu bersifat definitif, kalau keputusan itu sudah mampu menimbulkan akibat hukum yang dikehendaki. 
DIY/VI/2016 berupa peringatan tertulis yaitu, putusan Majelis Pengawas Wilayah Daerah Istimewa Yogyakarta tersebut bisa digunakan sebagai alasan pelapor untuk menggugat kepada Notaris yang bersangkutan untuk meminta ganti rugi secara perdata. Ketiga, dasar hukum penjatuhan sanksi terhadap Notaris tersebut yakni pada pemeriksaan Notaris tersebut telah terbuki bersalah, bukan merupakan persyaratan formal yang dilanggar. Notaris tersebut hanya melanggar prosedur, seharusnya yang membacakan isi akta adalah Notari. Dalam kasus tersebut di atas yang membacakan isi akta adalah pegawai Notaris, meskipun sudah melalui persetujuan dari pelapor, Notaris tetap perlu ditegur/diperingatkan, maka keputusannya hanya berupa peringatan tertulis.

\section{Daftar Pustaka}

\section{Buku}

Adjie, Habib, Kebatalan dan Pembatalan Akta Notaris, Refika Aditama, Badung, 2013. Ali, Achmad, Menguak Teori Hukum (Legal Theory) dan Teori Peradilan (Judicialprudence) Termasuk Interpretasi Undang-undang (Legisprudence), Kencana, Jakarta, 2009.

Anshori, Abdul Ghofur, Lembaga Kenotariatan Indonesia, Perspektif Hukum dan Etika, UII Press, Yogyakarta, 2009.

Kie, Tan Thong, Studi Notariat Serba-serbi Praktek Notaris, Ikhtiar Baru, Jakarta, 2007.

Marzuki, Peter Mahmud, Penelitian Hukum, Cetakan Pertama, Kencana, Jakarta, 2005.

Muhammad, Rusli, Potret Lembaga Pengadilan Indonesia, Raja Grafindo Persada, Jakarta, 2006.

Rahardjo, Satjipto, Masalah Penegakan Hukum, Suatu Tinjauan Sosiologis, Sinar Baru, Bandung, 1983.

Tobing, G.H.S. Lumban, Peraturan Jabatan Notaris (Notaris Reglement), Erlangga, Jakarta, 1999.

\section{Peraturan Perundang-undangan:}

Undang-undang Dasar Negara Republik Indonesia Tahun 1945.

Undang-undang Nomor 2 Tahun 2014 Tentang Perubahan Atas Undang-undang Nomor 30 Tahun 2004 Tentang Jabatan Notaris.

Kitab Undang-undang Hukum Perdata. 
Peraturan Menteri Hukum dan Hak Asasi Manusia Nomor 25 Tahun 2014 tentang Syarat dan Tata Cara Pengangkatan, Perpindahan, Pemberhentian, dan Perpanjangan Masa Jabatan Notaris.

_ Nomor 27 Tahun 2016 tentang Formasi Jabatan Notaris. , Nomor 7 Tahun 2016 Tentang Majelis Kehormatan Notaris. , Nomor M.02.PR.08.10 Tahun 2004.

, Nomor 7 Tahun 2016 tentang Majelis Kehormatan Notaris , Nomor 61 Tahun 2016 tentang Tata Cara Penjatuhan Sanksi Administratif Terhadap Notaris, yaitu dalam melakukan pemeriksaan terhadap Notaris

Keputusan Menteri Kehakiman dan Hak Asasi Manusia RI Nomor M-01.HT.03.01 tahun 2003 tentang Kenotarisan

Kode Etik Notaris Kongres Luar Biasa Ikatan Notaris Indonesia, Banten 29-30 Mei 2015.

Putusan Majelis Pengawas Wilayah Daerah Istimewa Yogyakarta Nomor 03/Pts/Mj.PWN DIY/VI/2016.

\section{Wawancara}

Nukman Muhammmad, sebagai Anggota Majelis Pemeriksa yang dibentuk oleh Majelis Pengawas Wilayah DIY, wawancara dilakukan pada Rabu 23 Agustus 2017, pukul 11.30 WIB.

, sebagai Anggota Majelis Pemeriksa yang dibentuk oleh Majelis Pengawas Wilayah DIY, wawancara dilakukan pada Senin 21 Agustus 2017, pukul 11.00 WIB. 